\title{
Hubungan Tingkat Pengetahuan Dengan Gejala Keracunan Pestisida pada Petani Penyemprot Pestisida Tanaman Holtikultura di Kecamatan Lembah Gumanti Kabupaten Solok Tahun 2019
}

\author{
Fadillah Ulva ${ }^{1}$, Nurul Prihastita Rizyana ${ }^{2}$, Afzahul Rahmi ${ }^{3}$ \\ ${ }_{1,2,3}$ STIKes Alifah Padang, JIn Khatib Sulaiman No 52 B Padang ${ }^{1}$ \\ Correspondence email: dilla_afdal@yahoo.com
}

\begin{abstract}
Abstrak. World Health Organization (WHO) dan United Nations Environment Program (UNEP) memperkirakan terdapat 1,5 juta kasus keracunan pestisida yang terjadi pada sektor pertania yang sebagian besar terjadi pada negara berkembang. Pestisida merupakan bahan berbahaya dan beracun (B3) yang harus dikelola dengan baik. Petani mendapatkan banyak keuntungan dengan penggunaan pestisida. Pestisida digunakan petani dalam mengendalikan serangan hama. Penggunaan pestisida yang tidak tepat dapat membahayakan petani. Tanaman holtikultura membutuhkan pestisida untuk mengendalikan serangan hama. Terdapat berbagai faktor yang dapat mempengaruhi tingkat keracunan pestisida pada petani, salah satunya adalah tingkat pengetahuan. Kurangnya pengetahuan tentang pestisida akan meningkatkan risiko terjadinya keracunan pestisida. Tujuan penelitian ini adalah untuk mengetahui hubungan antara tingkat pengetahuan dengan gejala keracunan pestisida pada petani tanaman holtikultura di Kecamatan Lembah Gumanti Kabupaten Solok Tahun 2019. Jenis penelitian ini adalah penelitian analitik observasional dengan desain cross sectional. Populasi dalam penelitian ini adalah seluruh petani holtikultura yang ada di Kecamatan Lembah Gumanti Kabupaten Solok tahun 2018 berjumlah 128 orang dengan jumlah sampel 56 orang. Pengambil sampel dilakukan dengan teknik proportional random sampling. Analisis data dilakukan secara univariat dan bivariat. Hasil penelitian menunjukkan $41,1 \%$ responden mengalami gejala keracunan yang berisiko, 46,4\% pengetahuan responden masih rendah. Berdasarkan uji statistik diketahui terdapat hubungan yang bermakna antara tingkat pengetahuan dengan gejala keracunan pestisida. Maka dapat disimpulkan bahwa tingkat pengetahuan akan mempengaruhi kejadian keracunan pestisida pada petani tanaman holtikultura. Dapat disarankan kepada petani melalui kelompok tani yang ada agar meningkatkan pengetahuan secara berkala.
\end{abstract}

Kata kunci : Tingkat Pengetahuan; Keracunan Pestisida; Petani

Abstract. The World Health Organization (WHO) and The United Nations Environment Program (UNEP) predict there are 1.5 million cases of pesticide poisoning that occur in the agricultural sector, most of which occur in developing countries. Pesticides are hazardous and toxic materials (B3) that must be managed properly. Farmers get many benefits from using pesticides. Pesticides are used by farmers to control pest attacks. Improper using of pesticides can endanger farmers. Horticulture plants need pesticides to control pest attacks. There are various factors that can affect the level of pesticide poisoning in farmers, one of them is the level of knowledge. Lack of knowledge about pesticides will increase the risk of pesticide poisoning. The purpose of this study was to determine the relationship between the level of knowledge with symptoms of pesticide poisoning in horticultural farmers in Lembah Gumanti, Solok Regency in 2019. The type of this research was observational analytic research with cross sectional design. The population in this study were all horticultural farmers in the Gumanti Lembah Subdistrict of Solok Regency in 2018 totaling 128 people with a sample of 56 people. The sample is done by proportional random sampling technique. Data analysis was carried out by univariate and bivariate. The results showed that $41.1 \%$ of respondents had symptoms of risky poisoning, $46.4 \%$ of respondents knowledge was still low. Based on statistical tests it is known that there is a significant relationship between the level of knowledge with symptoms of pesticide poisoning. It can be concluded that the level of knowledge will affect the incidence of pesticide poisoning in horticultural farmers. It can be suggested to farmers to increase knowledge regularly.

Keywords: Knowledge; Pesticide Poisoning; Farmers

\section{PENDAHULUAN}

Sektor pertanian merupakan sektor yang sangat penting dari pembangunan ekonomi di Indonesia. Sektor ini mendukung pembangunan ekonomi di Indonesia karena menghasilkan bahan pangan, bahan baku atau sumber energi serta untuk mengelola lingkungan hidup. Selain itu sektor ini juga banyak menyerap tenaga kerja sehingga juga berperan dalam roda perekonomian masyarakat (Ernawati, 2012).

Setiap hari ribuan petani dan para pekerja di sektor pertanian teracuni oleh pestisida (Kementan, 2015). Kejadian keracunan di dunia menurut World Health Orgazation (WHO) pada tahun 2012 terjadi sekitar 600.000 kasus. Di Bangladesh keracunan pestisida paling tinggi menyebabkan kematian, di Kamboja sekitar $88 \%$ dari 23.182 petani mengalami dampak akibat keracunan pestisida. Di Cina diketahui kejadian keracunan pestisida antara 53.000 sampai 123.000 orang (Shohib, 2013).
Pestisida merupakan bahan beracun dan berbahaya (B3), apabila tidak dikelola dengan baik maka akan berdampak negatif. Untuk itu perlu dilakukan pengendalian paparan pestisida terhadap orang-orang yang bekerja secara langsung dengan pestisida seperti petani dan penjual pupuk kimia serta yang tidak berhubungan secara langsung seperti mengkonsumsi buah-buahan, sayuran yang tercemar pestisida (Palupi, 2006).

Terdapat berbagai faktor yang dapat mempengaruhi tingkat keracunan pestisida pada petani. Tampudu, dkk (2010), menyimpulkan bahwa kadar aktivitas cholinesterase darah mengalami penurunan, dimana faktor-faktor eksternal yang berupa konsentrasi pestisida, lama kontak, masa kerja, luas lahan, cara menyemprot, frekuensi penyemprotan dan penggunaan alat pelindung diri berperan dalam menurunkan aktivitas cholinesterase darah atau mengakibatkan keracunan. Mahyuni (2015), menyatakan bahwa petani penyemprot 
pestisida di Kecamatan Berastagi berisiko mengalami keracunan pestisida melalui kontak langsung akibat tidak menggunakan alat pelindung diri yang lengkap, penggunaan pestisida yang tidak tepat mulai dari proses, pengetahuan yang rendah serta sikap kerja yang tidak tepat saat melakukan penyemprotan.

Tingginya angka tingkat keracunan pada petani dapat dipengaruhi oleh masih rendahnya pengetahuan petani tentang upaya pencegahan resiko keracunan terhadap pestisida tersebut. Menurut Notoatmodjo (2011), yang menyatakan bahwa perilaku yang didasari oleh pengetahuan akan lebih langgeng dari pada perilaku yang tidak didasari oleh pengetahuan. Berdasarkan penelitian Rogers (1992) dalam Soekidjo Notoatmodjo (2011), mengungkapkan bahwa sebelum orang mengadopsi perilaku baru, di dalam diri orang tersebut terjadi proses yang berurutan yaitu awarenes, interest, evalution, trial, dan adoption. Setelah seseorang mengetahui stimulus atau obyek, kemudian mengadakan penilaian atau pendapat terhadap apa yang diketahui, proses selanjutnya diharapkan ia akan melaksanakan atau mempraktikkan apa yang diketahui atau disikapinya.

Selain itu sikap kerja petani juga dapat mempengaruhi resiko terjadinya keracunan pestisida. Menurut Nurmianto (2008), sikap kerja merupakan suatu tindakan yang diambil tenaga kerja untuk melakukan pekerjaan. Untuk terwujudnya sikap menjadi suatu perbuatan nyata diperlukan faktor pendukung atau suatu kondisi yang memungkinkan antara lain fasilitas. Apabila penerimaan perilaku didasari oleh pengetahuan dan sikap, maka perilaku tersebut akan bersifat langgeng. Hal ini didukung oleh penelitian yang dilakukan oleh Diana (2013) di Kelurahan Rurukan Kecamatan Tomohon, didapatkan bahwa ada hubungan perilaku dengan kejadian keracunan pestisida pada petani sayur.

Tujuan penelitian ini adalah untuk mengetahui hubungan tingkat pengetahuan dengan gejala keracunan pada petani penyemprot pestisida tanaman holtikultura di Kecamatan Lembah Gumanti Kabupaten Solok Tahun 2019.

\section{METODE PENELITIAN}

Penelitian ini merupakan penelitian analitik dengan desain cross sectional. Populasi dalam penelitian ini adalah seluruh petani holtikultura yang ada di Kecamatan Lembah Gumanti Kabupaten Solok tahun 2018 berjumlah 128 orang. Berdasarkan rumus sampel Slovin, maka didapatkan sampel pada penelitian ini berjumlah 56 orang.

\section{HASIL DAN PEMBAHASAN Analisis Univariat}

Distribusi frekuensi gejala keracunan pestisida yang dirasakan PetaniHoltikultira di Lembah Gumanti Kabupaten Solok adalah sebagai berikut :

Tabel 1 Distribusi Frekuensi Gejala Keracunan Pestisida Pada Petani Holtikultura di Lembah Gumanti Kabupaten Solok

\begin{tabular}{ccc}
\hline Gejala Keracunan & $\mathrm{f}$ & $\%$ \\
\hline Ada Keluhan & 23 & 41,1 \\
Tidak Ada Keluhan & 33 & 58,9 \\
Total & 56 & 100 \\
\hline
\end{tabular}

Hasil penelitian pada tabel 1 diketahui bahwa sebagian besar responden mengalami gejala keracunan pestisida yaitu sebanyak 33 orang $(58,9 \%)$.

Distribusi frekuensi pengetahuan Petani Holtikultira di Lembah Gumanti Kabupaten Solok adalah sebagai berikut :

Tabel 2 Distribusi Frekuensi Pengetahuan Pada Petani Holtikultura di Lembah Gumanti Kabupaten Solok

\begin{tabular}{ccc}
\hline Pengetahuan & f & $\%$ \\
\hline Rendah & 26 & 46,4 \\
Tinggi & 30 & 53,6 \\
Total & 56 & 100 \\
\hline
\end{tabular}

Hasil penelitian pada tabel 2 diketahui bahwa sebagian besar responden mempunyai pengetahuan yang tinggi yaitu sebanyak 30 orang (53,6\%).

\section{Analisis Bivariat}

Hubungan pengetahuan dengan gejala keracunan pestisida yang dialami oleh Petani di Lembah Gumanti Kabupaten Solok adalah sebagai berikut :

Tabel 3 Hubungan Pengetahuan dengan Gejala Keracunan Pestisida Pada Petani Holtikultura di Lembah Gumanti Kabupaten Solok

\begin{tabular}{|c|c|c|c|c|c|c|c|}
\hline \multirow{3}{*}{ Pengetahuan } & \multicolumn{4}{|c|}{ Gejala Keracunan } & \multirow{2}{*}{\multicolumn{2}{|c|}{ Total }} & \multirow{3}{*}{$P$ Value } \\
\hline & \multicolumn{2}{|c|}{ Ada Keluhan } & \multicolumn{2}{|c|}{ Tidak Ada Keluhan } & & & \\
\hline & f & $\%$ & f & $\%$ & $\mathbf{f}$ & $\%$ & \\
\hline Rendah & 20 & 76,9 & 6 & 23,1 & 26 & 100 & \multirow{2}{*}{0,023} \\
\hline Tinggi & 13 & 43,3 & 17 & 56,7 & 30 & 100 & \\
\hline
\end{tabular}

Hasil penelitian pada tabel 3 menunjukkan bahwa proporsi responden yang mempunyai keluhan gejala keracunan pesitisida lebih banyak pada responden yang mempunyai pengetahuan rendah $(76,9 \%)$ dibandingkan dengan responden yang mempunyai pengetahuan tinggi $(43,3 \%)$. Hasil uji statistik diperoleh $p$ value sebesar $0,023(p<0,05)$, artinya terdapat hubungan yang bermakna antara pengetahuan dengan gejala keracunan pestisida yang dialami oleh Petani Holtikultura di Lembah Gumanti Kabupaten Solok.
Berdasarkan hasil analisis jawaban kuesioner yang dijawab oleh responden dapat diketahui bahwa $87,5 \%$ responden tidak mengetahui waktu yang tepat dalam melakukan penyemprotan. Menurut penelitian Marisa (2017) dijelaskan bahwa sebagian besar petani melakukan penyemprotan pestisida menurut musim, jika musim hujan maka serangan hama akan lebih banyak daripada musim kemarau, tanaman bawang merah rentan terkena hama ulat pada musim hujan sehingga tanaman lebih cepat menjadi busuk sebelum dipanen. 
Untuk itu biasanya petani selalu berpatokan pada keadaan tanaman bawang merah di lapangan. Petani biasanya melakukan penyemprotan lebih dari 2 kali dalam seminggu, bahkan melakukan penyemprotan setiap dua kali sehari pada musim hujan. Petani melakukan penyemprotan umumnya pada pagi hari, mulai pukul $07.00-12.00$, dan dilanjutkan pada pada sore hari atau besok paginya lagi, sebanyak $3-4$ kali dalam seminggu.

Tingginya angka tingkat keracunan pada petani dapat dipengaruhi oleh masih rendahnya pengetahuan petani tentang upaya yang dilakukan dalam upaya penanganan sisa pestisida setelah melakukan penyemprotan pestisida. Menurut Notoatmodjo (2011), menyatakan bahwa perilaku yang didasari oleh pengetahuan akan lebih langgeng dari pada perilaku yang tidak didasari oleh pengetahuan.

Hasil analisa bivariat menunjukkan ada hubungan antara tingkat pengetahuan petani dengan gejala keracunan pada petani tanaman holtikultura. Hal ini dikarenakan rendahnya pengetahuan petani maka perilaku petani dalam melakukan penanganan pestisida dapat mengakibatkan risiko petani terpapar oleh pestisida lebih besar. Pengetahuan tentang penanganan pestisida berisikan pengetahuan tentang memilih, menyimpan, meracik dan pelaksanaan penyemprotan.

\section{SIMPULAN}

Berdasarkan hasil penelitian dapat disimpulkan

1. Hampir separuh petani $(41,1 \%)$ petani mengalami gejala keracunan pestisida kategori berisiko.

2. Hampir separuh petani $(46,4 \%)$ memiliki pengetahuan yang rendah

3. Terdapat hubungan yang bermakna antara tingkat pengetahuan dengan gejala keracunan pestisida pada Petani Penyemprot Pestisida Tanaman Holtikultura di Kecamatan Lembah Gumanti Kabupaten Solok Tahun 2018.

\section{DAFTAR PUSTAKA}

Afriyanto, 2008. Kajian Keracunan Pestisida pada Petani Penyemprot Cabe di Desa Candi Kec. Bandungan Kabupaten Semarang. [Tesis IImiah]. Semarang: Universitas Negeri Semarang

Anam, Haerul, Nurhidayati, Maruni Wiwin Diarti, dan Zaenal Fikri. Kadar Enzim Kholinesterase Darah Petani Terpapar Pestisida Yang Diberikan Rimpang Temulawak (Curcuma xanthorrhiza Roxb). Jurnal Kesehatan Prima Volume : 9, No.2, Agustus 2015, Halaman : 1546-1558 ISSN Print : 1978 - 1334, ISSN Online : 2460 - 8661

Depkes RI, 1992. Pemeriksaan Kadar Cholinesterase Darah dengan Tintometer Kit . Jakarta.

Djojosumarto, 2008. Panduan Lengkap Pestisida dan Aplikasinya. Jakarta : Agromedia.

Harianto, 2009. Menghitung Kerusakan Akibat Gangguan Hama. Jakarta : Agromedia:

Hartawan,2000. Pengukuran Tingkat Aktivitas Cholinesterase Darah pada Petani Pengguna Pestisida Golongan Organophosphot di Dusun Embu Karung, Desa Montong Gamang, Kecamatan Kopang, Kabupaten Lombok Tengah
Tahun 2000. Karya Tulis.Mataram; Akademi Kesehatan Lingkungan YAPMA.

Kementan, 2017. Pengambilan Sampel Untuk Pemeriksaan Residu Pestisida. Kementan : Jakarta

Panut, Djojosumarto, 2008. Pestisida dan Aplikasinya. Jakarta : PT Agromedia Pustaka.

Rahmawati dan Martiana. 2014. Pengaruh Faktor Karakteristik Petani dan Metode Penyemprotan Terhadap Kadar Kolinesterase. The Indonesian Journal of Occupational Safety, Health and Environment. Fakultas Kesehatan Masyarakat Universitas Airlangga. (Online), Vol. 1, No. 1.

Sartono, 2001. Racun dan Keracunan. Jakarta : Widya Medika. 